\title{
Pensononowoor
}

2018, vol. 79, 131-139

http://dx.doi.org/10.12657/denbio.079.012

\author{
Katarzyna Kmieć, Magdalena Pogorzelec', Barbara Hawrylak-Nowak, \\ Barbara Banach-Albińska
}

\section{Salix lapponum L. vs. phytophagous insects - an assessment of the risks and the reaction of plants}

Received: 20 October 2017; Accepted: 28 March 2018

\begin{abstract}
Since the 1950s, a significant decrease in the population numbers of Salix lapponum L. has been observed in Poland, particularly in the Polesie Lubelskie region. One of the most important threats comes from the biotic environment including interactions at the trophic level. An unidentified issue was the occurrence and importance of phytophagous insects inhabiting S. lapponum in terms of real threats to growth and development as well as specific plant reactions to herbivores. The aim of the study was to recognize the occurrence of phytophagous insects inhabiting S. lapponum, i.e. an endangered species, and estimation of physiological changes caused by the herbivorous species feeding.

The field study was conducted in a locality of $S$. lapponum population in the peat bog near Bikcze Lake (Polesie Lubelskie Region) in 2014-2015. In each growing season from the end of April to September, 100 stems of $S$. lapponum shoots with similar length were examined once a month. Selected parameters of chlorophyll $a$ fluorescence were measured and the accumulation of $\mathrm{H}_{2} \mathrm{O}_{2}$ was visually detected in leaves collected from the control plants and from those attacked by herbivores using the 3',3-diaminobenzidine (DAB) method. We found the presence of 8 phytophagous insect species from 4 orders (Coleoptera, Diptera, Hemiptera and Lepidoptera) on S. lapponum. Most of the shoots were inhabited by Lochmea caprea, Aphrophora salicina and Aphis farinosa. On the basis of the measurements of chlorophyll $a$ fluorescence and $\mathrm{H}_{2} \mathrm{O}_{2}$ accumulation under phytophagous insects feeding, we have demonstrated that $S$. lapponum was able to maintain photosynthesis under insect attack and that the accumulation of $\mathrm{H}_{2} \mathrm{O}_{2}$ in leaf blades indicates local rather than systemic stress response to herbivore feeding.

Phytophagous insects feeding caused relatively weak disruptions to host plant physiology and S. lapponum is able to maintain photosynthetic efficiency under insect attack. Variation in plant traits influence host plant selection and performance of herbivorous insects. Comparative studies are needed to assess the species composition and population numbers of insects occurring on plants from other S. lapponum populations. Detailed knowledge of the biotic factors affecting the occurrence of $S$. lapponum would facilitate establishment of the form of its conservation.
\end{abstract}

Keywords: arthropods, chlorophyll a fluorescence, conservation, downy willow, $\mathrm{H}_{2} \mathrm{O}_{2}$ accumulation

Addresses: K. Kmieć, Department of Plant Protection, University of Life Sciences in Lublin, Leszczyńskiego 7, 20-069 Lublin, Poland

M. Pogorzelec, Department of Hydrobiology and Protection of Ecosystems, University of Life Sciences in Lublin, Dobrzańskiego 37, 20-262 Lublin, Poland, e-mail: magdalena.pogorzelec@up.lublin.pl

B. Hawrylak-Nowak, Department of Plant Physiology, University of Life Sciences in Lublin, Akademicka

15, 20-950 Lublin, Poland

B. Banach-Albińska, Department of Zoology, Animal Ecology and Wildlife Management, University of Life Sciences in Lublin, Akademicka 13, 20-950 Lublin, Poland

*Corresponding author 


\section{Introduction}

Interactions among plants and insects create an important component of terrestrial environment. Those relationship have a crucial role in the matter recycling, energy and nutrient flows in ecosystems (Santos \& Fernandes, 2010). Plants provide shelter, food resources and oviposition sites for insects. However, herbivores might be extremely harmful to plants, thus plants present a wide spectrum of different defense mechanism including chemical and physical barriers. Moreover, both organisms are under other biotic and abiotic environmental pressures that have an important impact on interaction system (Santos \& Fernandes, 2010; Charles et al., 2014). Since the 1950, a significant decrease in the population numbers of downy willow Salix lapponum L. has been observed in Poland, particularly in the Polesie Lubelskie region. The populations size known from literature data have dropped by almost $80 \%$ and this trend still persists (Kaźmierczakowa \& Zarzycki, 2001). Its main causes are attributed to changes in habitat conditions in natural stands of this species. These are primarily changes in water relations, which result in the process of ecological succession in peatland ecosystems (Serafin et al., 2015). The appearance of expanding species, i.e. Phragmites australis (Cav.) Trin. ex Steud., Salix cinerea L., or Betula humilis Schrank, adversely affects the functioning of taxa characteristic of peatland habitats, predominantly by changing the values of abiotic and biocenotic factors in such habitats (Pogorzelec et al., 2014b).

One of the most important threats comes from the biotic environment including interactions at the trophic level. In natural communities and in agroecosystems, insects are known to affect the growth, competitive ability, and population dynamics of their host plants (Charles et al., 2014). Direct tissue consumption by defoliators and cellular disruption by piercing-sucking insects trigger a complex of physiological responses in the host plant (War et al., 2012). These responses affect the life processes such as photosynthesis. Among the indirect effects on physiological processes, photosynthesis disruption can have the most significant influence on plant growth and performance (Nabity et al., 2009). Moreover, several studies have revealed inhibition of photosynthesis following insect oviposition, even where eggs are laid on the leaf surface in the absence of tissue damage, which suggests that down-regulation of photosynthesis is a plant-driven response to the perception of stress rather than a secondary physiological response to tissue damage (Kerchev et al., 2012). It is well established that the emission of chlorophyll a fluorescence provides an indicator of the primary photochemistry of photosynthesis (Murchie \& Lawson, 2013). Measurements of chlorophyll a have been applied to demonstrate that impairment of the photochemistry (direct or indirect) upon insect attack is a common physiological disorder (Nabity et al., 2009; Golan et al., 2015).

Photosynthesis disturbances that are often observed under insect attack are considered as the main cause of increased reactive oxygen species (ROS) accumulation and induction of oxidative stress (Kerchev et al., 2012). Therefore, the oxidative status of plants is an important strategy that enables plants to defend themselves against various biotic and abiotic stresses. Reactive oxygen species serve a variety of signaling functions and can act directly as toxins. An apoplastic burst of ROS acts as a first barrier against subsequent attack by pathogens and herbivores. Among all the ROS, highly stable and easily diffusible $\mathrm{H}_{2} \mathrm{O}_{2}$ is a crucial component of induced defense response in plants. Besides having a direct effect on phytophagous arthropods, $\mathrm{H}_{2} \mathrm{O}_{2}$ stimulates a cascade of reactions in plant cells that lead to the expression of defense genes (Torres, 2010). Moreover, oxidative changes in plants after insect attack cause oxidative damage to the insect midgut, mainly due to accumulation of $\mathrm{H}_{2} \mathrm{O}_{2}$ (Krishnan et al., 2007; Zhu-Salzman et al., 2008). Many physiological and molecular responses in plants against insect attack are triggered by $\mathrm{H}_{2} \mathrm{O}_{2}$, and its levels remain elevated as long as the herbivore attack persists (War et al., 2012).

Plant defenses against phytophagous insects are mediated by plant characteristics that affect the herbivore's biology such as mechanical protection on the plant surface or production of toxic chemicals i.e. phenolic secondary metabolites, that either kill or retard the development of herbivores (War et al., 2012). Trichomes play an imperative role in plant defense against many insect species and exert both toxic and deterrent effects (Scott-Brown et al., 2016). Trichome density negatively affects the ovipositional behavior, feeding, and larval nutrition of herbivores (Molina-Montenegro et al., 2006). In addition, dense pubescence affect herbivory mechanically and interfere with the movement of insects and other arthropods on the plant surface, thereby reducing their access to leaf epidermis (Hanley et al., 2007). However, leaves of Corylus avellana L. characterized by greater thickness, density of trichomes and a higher level of defense compounds were favorable food source for larvae of monophagous beetle Altica brevicollis coryletorum Král (Łukowski et al., 2015). On the other hand, leaves of various Salix species are defended by trichomes and common secondary metabolites, mainly salicylates, which are effective against unspecialized herbivores, deterring them from feeding and increasing larval mortality (Volf et al., 2015).

An unidentified issue was the occurrence and importance of phytophagous insects inhabiting S. lapponum in terms of real threats to growth and 
development as well as physiological plant reactions to herbivores. We attempted to verify the hypothesis that insects inhabiting $S$. lapponum could be a real threat to the proper functioning of populations and the condition of individuals of the examined species in natural habitats in eastern Poland. Field and laboratory studies were conducted to: a) determine the species composition of phytophagous insects inhabiting S. lapponum populations in their natural habitats (it was important to find out whether the insect species feeding on the examined plant were specific or appeared accidentally); b) indicate species that pose a real threat to the condition of plants; c) assess physiological plant response to insect feeding by determination of chlorophyll $a$ fluorescence parameters and $\mathrm{H}_{2} \mathrm{O}_{2}$ accumulation in leaf tissues.

\section{Material and Methods}

\section{Plant species}

Salix lapponum L. is a shrub reaching a height of 1 to 2 meters. It is a dioecious plant blooming in May and June. Downy willow has specific leaves with silvery grey napped underside characterized by long, thin-walled, tubular, twisted, very sinuous trichomes and a thick indumentum (Binns \& Blunden, 1980; Pogorzelec, 2008a; Serafin et al., 2015). Salix lapponum frequently occurs in subarctic and boreal regions of northern and north-eastern Europe and western Siberia. Some isolated populations are also recorded in the mountains of Central and South Europe and in Scotland (Kaźmierczakowa \& Zarzycki, 2001; Podbielkowski, 2002). It grows in sunny or partially shaded locations, and prefers oligotrophic or mesotrophic habitats rich in organic matter with a $\mathrm{pH}$ value of 4-6 (Pogorzelec, 2008; Serafin et al., 2015). In Poland, the S. lapponum species is on the verge of extinction and, as a glacial relict, it has the status of an endangered species in Poland (EN; 'Red Data Book' status) as well as a vulnerable plant (EN by IUCN) (Kaźmierczakowa \& Zarzycki, 2001; Mirek et al., 2006). It occurs in the Łęczna-Włodawa Lakeland in the Polesie National Park, in the Biebrza National Park, and in Puszcza Knyszyńska (Fijałkowski \& Izdebski, 2002; Urban \& Gawlik, 2003; Pogorzelec et al., 2014b). There are also two populations in the Karkonosze Mountains forming an endemic Salicetum lapponum association W. Mat. 1965.

\section{Study area and population}

The field study was conducted in a locality of $S$. lapponum population in a peat bog near Bikcze Lake

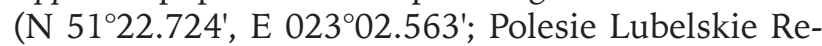
gion) in 2014-2015. This particular population was selected due to its size (the largest in Eastern Poland - about 300 individuals), the stable sex ratio (1:1) and optimal genetic structure (lack of clonal individuals) that confirms its proper functioning (Głębocka \& Pogorzelec, 2017).

\section{Entomological analyses}

In each growing season from the end of April to September, 100 random stems of $S$. lapponum with 40 $\mathrm{cm}$ length were examined once a month $(n=1000)$. Insect individuals and/or signs of their feeding were observed/identified in the field or collected in glass tubes sealed with a cotton wool plug and examined under a microscope in the laboratory. Intact and damaged leaves were counted on each analyzed twig. Belowground herbivores were not examined. Preimaginal forms of the insects were collected and reared in the laboratory to the adult stage. The specimen species were identified using available keys (Nowacka, 1996; Beiger, 2001; Łabanowski \& Soika, 2003; Blackman \& Eastop, 2017).

\section{Physiological tests}

Chlorophyll $a$ fluorescence parameters are commonly used to characterize the primary photosystem II (PSII) photochemistry, which is interrelated with the photosynthetic capacity. In our study, the selected parameters of chlorophyll $a$ fluorescence included the minimal $\left(\mathrm{F}_{0}\right)$ and maximal $\left(\mathrm{F}_{\mathrm{m}}\right)$ level of fluorescence and the maximum quantum yield of PS II $\left(\mathrm{F}_{\mathrm{v}} /\right.$ $F_{m}$, where $\left.F_{v}=F_{m}-F_{0}\right)$. An increase in $F_{0}$ or a decrease in $F_{m}$ and $F_{v} / F_{m}$ reflect disturbance in photosynthesis caused e.g. by environmental stresses (Murchie \& Lawson, 2013). Measurements were made using a Handy PEA fluorimeter (Hansatech Instruments Ltd., UK) on the leaves of control plants (without insects and visible damage) and on the leaves inhabited by selected insect species. The leaves of S. lapponum were adapted to darkness for 15 min before the measurements by attaching special light-exclusion clips. The measurements were carried out on leaves located in the middle part of the shoot, and at least 30 measurements were made for the control shrubs and for those attacked by the identified phytophagous arthropods in each growing season.

The accumulation of $\mathrm{H}_{2} \mathrm{O}_{2}$ was visually detected in the leaves using the 3',3-diaminobenzidine (DAB) method (Deuschle et al., 2004). Healthy and damaged leaves were collected from different plants (control or inhabited by herbivores). The leaves were transported to the laboratory in plastic tubes filled with distilled water and immediately immersed in an aqueous solution of DAB $\left(1 \mathrm{mg} \mathrm{ml}^{-1} \mathrm{w} / \mathrm{v} ; \mathrm{pH}=\right.$ 4.0) for $12 \mathrm{~h}$ in the dark at room temperature. The $\mathrm{DAB}$ solution was freshly prepared before staining in 
order to avoid its auto-oxidation. The staining was terminated by immersion of the leaves in hot water and then in warm $90 \%$ ethanol until they were decolorized, except for the deep brown polymerization product produced by DAB in the presence of $\mathrm{H}_{2} \mathrm{O}_{2}$. In our previous study using quantitative analysis and visualisation of $\mathrm{H}_{2} \mathrm{O}_{2}$ in leaves, we found that the uneven distribution of this compound within the leaf lamella may distort its quantitative analysis and, in consequence, can give quite different results even for the same leaf (Hawrylak-Nowak et al., 2015). Because the preliminary studies have shown very heterogeneous accumulation of this compound $S$. lapponum leaves attacked by insects, in this study the accumulation and location of $\mathrm{H}_{2} \mathrm{O}_{2}$ were assessed only visually and the most representative objects were photographed.

\section{Data analysis}

One-way analysis of variance (ANOVA) followed by Tukey's test at the 0.05 probability level was used to investigate the influence of feeding of the most numerous insects (Aphrophora salicina, Aphis farinosa and Lochmaea caprea) on chlorophyll a fluorescence parameters of S. lapponum. The images of histochemical detection of $\mathrm{H}_{2} \mathrm{O}_{2}$ were collected from at least fifteen leaf blades using at least four different individuals for both the control shrubs and those attacked by the herbivore insects. The leaves were harvested twice during each growing season, but between seasons and between the harvest dates, we did not observe any visual differences in the accumulation and localization of $\mathrm{H}_{2} \mathrm{O}_{2}$ in the control and damaged leaves. Therefore we have presented the most representative images for given objects.

\section{Results}

We detected the presence of 8 phytophagous insect species from 4 orders on the $S$. lapponum shoots (Table 1). Most species belonged to the order Coleoptera. Both larvae and imagines had chewing mouthparts. Crepidodera aurata Marsh. and Lochmea caprea (L.) fed on willow leaves, while Meligethes aeneus (Fabr.) fed on pollen. Two species, Caloptilia stigmatella (Fabr.) and Pandemis heparana (Den. \& Schiff.), were classified to the order Lepidoptera. Only larvae were observed on the plants. They had chewing mouthparts and fed on willow leaves. The guild of sap-sucking specialists (Order Hemiptera) was formed by Aphrophora salicina (Goeze) and Aphis farinosa (Gmel.). Aphids fed on the top parts of the shoots and young leaves, while planthoppers fed only on the shoots. The order Diptera was represented by one species, Rhabdophaga rosaria (Loew). Its larvae were observed in characteristic galls.

Most of the shoots were inhabited by larvae of $L$. caprea and A. salicyna, i.e. $65.2 \%$ and $43.2 \%$ of the analyzed shoots, respectively (Table 1 ). Colonies of A. farinosa were noted on $16 \%$ of the S. lapponum shoots. Other species inhabited from 1.4 to $4.2 \%$ of the analysed shoots. The larvae of $L$. caprea scraped the leaves, which reduced their biologically active surface. They fed in groups and damaged more than $47 \%$ of leaves on the attacked plants. The larvae of A. salicyna fed on the shoots inside the typical foam nest. We observed more than four nests per shoot on average. Aphis farinosa colonies consisting of up to 30 specimens inhabited the bottom side of young leaves and the tops of the shoots. In the case of both sap-sucking species, no visible damage was noted on the shoots. Caloptilia stigmatella inhabited $4 \%$ of

Table 1. Phytophagous insects infesting Salix lapponum L. growing in a peat bog in 2014-2015

\begin{tabular}{|c|c|c|c|c|}
\hline Insect species/systematics & $\begin{array}{l}\text { Developmental } \\
\text { stage }\end{array}$ & Mouthparts & $\begin{array}{l}\% \text { of infested } \\
\text { shoots }\end{array}$ & $\begin{array}{c}\text { Mean number of dam- } \\
\text { aged leaves on infested } \\
\text { shoots [in \%] }\end{array}$ \\
\hline \multirow{2}{*}{$\begin{array}{l}\text { Aphrophora salicina (Goeze) } \\
\text { Hemiptera: Auchenorrhyncha: Cercopidae }\end{array}$} & larvae & \multirow[t]{2}{*}{ sap-sucking } & 43.2 & $4.3^{*}$ \\
\hline & imagines & & 8.1 & not found \\
\hline $\begin{array}{l}\text { Aphis farinosa (Gmel.) } \\
\text { Hemiptera: Sternorrhyncha: Aphididae }\end{array}$ & larvae and imagines & sap-sucking & 16.4 & $2.3^{*}$ \\
\hline Lochmaea caprea (L.) & imagines & chewing & 5.3 & not found \\
\hline Coleoptera: Chrysomelidae & larvae & & 65.7 & 47.1 \\
\hline $\begin{array}{l}\text { Crepidodera aurata Marsh. } \\
\text { Coleoptera: Chrysomelidae }\end{array}$ & imagines & chewing & 2.1 & not found \\
\hline $\begin{array}{l}\text { Meligethes aeneus Fabr. } \\
\text { Coleoptera: Nitidulidae }\end{array}$ & imagines & chewing & 1.4 & not found \\
\hline $\begin{array}{l}\text { Caloptilia stigmatella (Fabr.) } \\
\text { Lepidoptera: Gracillaridae }\end{array}$ & larvae & chewing & 4.2 & 1.6 \\
\hline $\begin{array}{l}\text { Pandemis heparana (Den. \& Schiff.) } \\
\text { Lepidoptera: Tortricidae }\end{array}$ & larvae & chewing & 3.6 & 2.7 \\
\hline $\begin{array}{l}\text { Rhabdophaga rosaria (Loew) } \\
\text { Diptera: Cecidomyiidae }\end{array}$ & larvae & minute styliform mandibles & 2.5 & $1^{*}$ \\
\hline
\end{tabular}

*mean number of colonies/galls on an infested shoot. 
Table 2. Selected parameters of chlorophyll a fluorescence in Salix lapponum L. leaves under biotic stress caused by insect feeding

\begin{tabular}{llll}
\hline \multicolumn{1}{c}{ Insect species } & \multicolumn{1}{c}{$\mathrm{F}_{0}$} & $\mathrm{~F}_{\mathrm{m}}$ & $\mathrm{F}_{\mathrm{v}} / \mathrm{F}_{\mathrm{m}}$ \\
\hline Aphis farinosa & $442.29 \pm 73.63 \mathrm{a}$ & $1562.71 \pm 168.17 \mathrm{ab}$ & $0.705 \pm 0.06 \mathrm{n} . \mathrm{s}$. \\
Aphrophora salicina & $354.50 \pm 45.01 \mathrm{~b}$ & $1394.00 \pm 268.36 \mathrm{~b}$ & $0.742 \pm 0.03$ \\
Lochmaea caprea & $372.00 \pm 92.64 \mathrm{ab}$ & $1568.75 \pm 282.59 \mathrm{ab}$ & $0.759 \pm 0.06$ \\
control & $432.27 \pm 44.83 \mathrm{a}$ & $1662.86 \pm 106.60 \mathrm{a}$ & $0.740 \pm 0.03$ \\
\hline
\end{tabular}

Mean values $( \pm S D)$ sharing the same letter in the column are not significantly different at $\mathrm{p}<0.05(\mathrm{n}=60)$; n.s. $=$ not significant.

the S. lapponum twigs. Its larvae fed in characteristic mines in the apical surface of the leaves. Pandemis heparana was noted on $3 \%$ of the shoots. Its larva created a nest by rolling the leaves together with silk. It fed inside, damaging almost 3 leaves on the shoot on average. Rosette galls of $R$. rosaria were noted on $2 \%$ of the $S$. lapponum shoots.

The analysis of the chlorophyll $a$ fluorescence parameters show that only the presence of $A$. salicina exerted a significant effect on $\mathrm{F}_{0}$ and $\mathrm{F}_{\mathrm{m}}$ values, contributing to their decrease in relation to the control plants. On the other hand, the maximum quantum yield of PS II photochemistry $\left(\mathrm{F}_{\mathrm{r}} / \mathrm{F}_{\mathrm{m}}\right)$ was not affected by the phytophagous insect feeding, regardless of the insect species (Table 2).

Histochemical detection of $\mathrm{H}_{2} \mathrm{O}_{2}$ in leaf blade tissues using $\mathrm{DAB}$ staining revealed that the accumulation of $\mathrm{H}_{2} \mathrm{O}_{2}$ occurred near wound sites caused by insect feeding. However, $\mathrm{H}_{2} \mathrm{O}_{2}$ did not spread throughout the veins and tissues and was mainly localized in the damaged zone (Fig. 1).

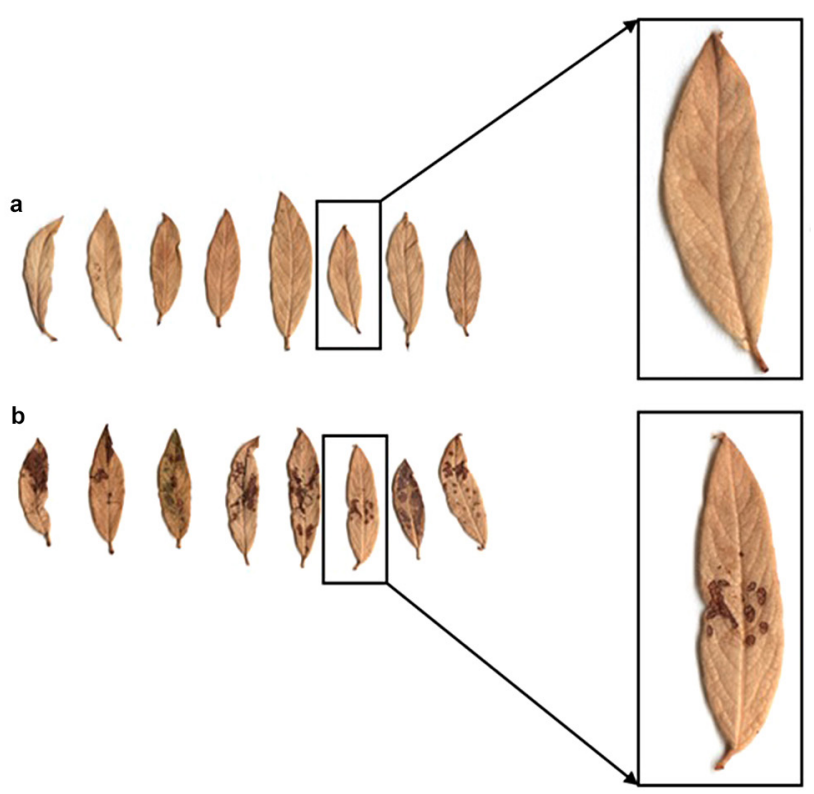

Fig. 1. Histochemical detection of $\mathrm{H}_{2} \mathrm{O}_{2}$ using DAB staining in the control (a) and herbivore-infested (b) leaves of downy willow. The intense deep brown color indicates the presence and accumulation of $\mathrm{H}_{2} \mathrm{O}_{2}$.

\section{Discussion}

In this study, we found 8 species of insects belonging to 4 orders feeding on S. lapponum. Photosynthetic efficiency did not seem affected by the presence of the insects, and the accumulation of $\mathrm{H}_{2} \mathrm{O}_{2}$ in leaves after damage was localized rather than systemic response to herbivores feeding.

As a group of trees and shrubs widespread in Europe, Salix genus provide habitats of rich biodiversity in their native environments. More than 200 arthropod species inhabit willows in Central Europe. As an important food source, they are associated with a wide range of phytophagous insects (Georgiev et al., 2004; Canty et al., 2016). However, only a relatively small number of herbivorous species regularly cause considerable damage to Salix trees, which reduces their economic or environmental value (Charles et al., 2014). Insect herbivores have been divided into generalists tolerating a wide array of defenses present in most plants, and specialists using a specific range of host plants releasing defense compounds (Fürstenberg-Hägg et al., 2013). Most of the phytophagous insect species observed in 2014-2015 on S. lapponum were presumably specific to the Salicaceae family. It seems that, these herbivores were not directly related to S. lapponum. Their presence in the biocoenosis of the peat bog near Lake Bikcze was probably caused by the species composition of the phytocoenosis, with the numerous occurrence of other willow species (S. cinerea, Salix rozmarinifolia L., Salix pentandra L., Salix aurita L.) (Pogorzelec, 2008a; Pogorzelec \& Wojciechowska, 2011; Pogorzelec et al., 2014).

Lochmea capreae occurs in Europe, Lapland, the British Isles, the Balkans, and Lake Baikal. Adult beetles make holes in willow and birch leaves and attack the buds and bark of annual shoots (Rokytová et al., 2004). This species was indicated in the Polesie National Park and recognized as eudominant among chrysomelid species in transitional and high peat bogs (Ścibior, 2010). Contrary to literature (Rokytová et al., 2004), in our study, eggs of this species were noted on the $S$. lapponum leaves. The beetles of another chrysomelid, C. aurata, produce small holes or pits in the leaf by eating through the epidermis and underlying tissues. This species is very common 
throughout Poland as well as abundant and having a wide range in Europe (Canty et al., 2016). However, research conducted by Ścibior (2010) did not reveal C. aurata in the peat bogs of the Polesie National Park. We found only few individuals and no visible damage caused on infested leaves. Crepidodera aurata and $L$. capreae occur abundantly in Salix plantations in south-eastern Poland (Czerniakowski, 2000; 2006). Aphrophora salicina was found to attack about $42 \%$ of the $S$. lapponum twigs. This species commonly inhabits various species of willow, and is also mentioned as a pest in willow plantations (Nijak, 2009; Czerniakowski, 2010; Ropek \& Fraczzek, 2016). Aphis farino$s a$ was the only aphid species found on S. lapponum in our study. Small colonies inhabited the bottom side of young leaves and the tops of shoots. Of 120 aphid species inhabiting willows worldwide, only 6 have been indicated on S. lapponum (Blackman \& Eastop, 2017). In spring and early summer, $A$. farinosa formed dense colonies, attended by ants, on young shoots of the willows. It is a monoecious species with a sexual generation occurring already in summer (Blackman \& Eastop, 2017). Both hemipterous species namely, A. farinosa and A. salicina are serious pests of ornamental willows in Polish nurseries (Eabanowski \& Soika, 1998). Less common gall inducing insects were represented by $R$. rosaria. Adult females oviposit into expanding willow shoots. The activity of the gall former inhibits further lengthwise growth of the shoot, with concomitant reduction of leaf growth and increased production of trichomes. A characteristic 'leaf rose' is formed at the tip of a galled shoot (Nyman et al., 2011). This species is mentioned as a local pest of Salix species (Charles et al., 2014). In our study, caterpillars of C. stigmatella and P. hepara$n a$ inhabited $4 \%$ and $3 \%$ of the $S$. lapponum shoots, respectively. The larvae of $C$. stigmatella were found to feed on different species of willows and poplars. Young larvae mine the leaves of their host plant, while older instars continue living freely under a leaf fold (Łabanowski \& Soika, 2003). Wrzesińska and Wawrzyniak (2012) found this species in high densities (as a eudominant) on Salix viminalis L. plantations in the Kujawy and Pomorze Province. Pandemis heparana has two generations per year, and its larvae are considered a pest of trees and shrubs. They live in rolled leaves and are polyphagous, feeding on various deciduous trees and shrubs, including Quercus sp., Salix sp., Betula sp., Lonicera sp., Sorbus sp., Malus sp., and Pyrus sp. (Łabanowski \& Soika, 2003).

The magnitude of the insect herbivory effect on photosynthetic capacity is multifaceted, depending mostly on the type of feeding habits and the specificity of plant defense responses (Nabity et al., 2009). It has been found that plant genotypes that are capable to maintain photosynthesis under insect attack often exhibit greater resistance, which supports the hypothesis that insect-induced changes in photosynthesis are genetically programmed (Kerchev et al., 2012). In general, healthy plants have photosynthetic efficiency $\left(F_{v} / F_{m}\right)$ of $0.8-0.9$, while plants suffering from stress have ratios of ca. 0.3- 0.7 (Öquist \& Wass, 1988). The $\mathrm{F}_{/} / \mathrm{F}_{\mathrm{m}}$ obtained in our study ranged between 0.705 and 0.759 and were a slightly below the optimal values given by Öquist \& Wass (1988) and Murchie \& Lawson (2013). We believe that under natural conditions, due to large fluctuations in environmental factors affecting photosynthesis, the $\mathrm{F}, \mathrm{F}_{\mathrm{m}}$ recorded by us for $\mathrm{S}$. lapponum can be considered as optimal. Moreover, we did not find significant impairment of photosynthesis (e.g. $\mathrm{F}_{v} / \mathrm{F}_{\mathrm{m}}$ as a proxy for maximum quantum yield of PSII) in the plants inhabited by phytophagous insects, compared to the control plants. Only A. salicina feeding reduced the $\mathrm{F}_{0}$ and $\mathrm{F}_{\mathrm{m}}$ values, but the decrease in $\mathrm{F}_{0}$ is not a sign of the negative impact of stress factors on chlorophyll $a$ fluorescence (Murchie \& Lawson, 2013). Therefore, we assume that the photosynthetic capacity of $S$. lapponum can be maintained in conditions of plant infestation by the examined insect species. There is very little information available on the measurement of chlorophyll $a$ fluorescence in S. lapponum. Odasz-Albrigtsen et al. (2000) reported that S. lapponum growing in the birch forests of Norway had an $F / F_{m}$ value ranging between 0.594 and 0.695 .

The involvement of ROS in defensive responses of plants towards insect herbivores is well established. Infection or the action of pathogen-derived elicitors cause an oxidative burst characterized by overproduction of $\mathrm{H}_{2} \mathrm{O}_{2}$ (Gatehouse, 2002). In our study, we found that the feeding of herbivores on $S$. lapponum leaves induced accumulation of $\mathrm{H}_{2} \mathrm{O}_{2}$ very close to the area of damage. Similarly, other studies have provided direct evidence for $\mathrm{H}_{2} \mathrm{O}_{2}$ accumulation following plant infestation by either chewing or piercing-sucking insects (Kerchev et al., 2012, and references therein). For example, a study concerning infestation of lima bean by the chewing caterpillar Spodoptera littoralis Boisd. revealed accumulation of $\mathrm{H}_{2} \mathrm{O}_{2}$ close to the zone of wounding within $3 \mathrm{~h}$ following either mechanical injury or caterpillar feeding (Maffei et al., 2006). The high levels of $\mathrm{H}_{2} \mathrm{O}_{2}$ have been implicated in the induction of cell death in the hypersensitive response to pathogens. The accumulation of $\mathrm{H}_{2} \mathrm{O}_{2}$ has previously been observed at a distance away from the injured leaf area, but only after insect feeding, suggesting a potential function of $\mathrm{H}_{2} \mathrm{O}_{2}$ as a systemic diffusible signaling molecule (Gatehouse, 2002; Kerchev et al., 2012). However, in the present study, we did not detect $\mathrm{H}_{2} \mathrm{O}_{2}$ in vascular bundles, which implies local rather than systemic stress response to herbivore feeding.

Czerniakowski (2006) and Nijak (2011) reported that different insect species showed a clear 
preference for cultivars and clones of $S$. viminalis. This is associated with the morphological and anatomical structures of plants and with biochemical interactions between the insect and the host plant. To avoid insect attack, plants produce specialized morphological structures or secondary metabolites and proteins (War et al., 2012). Binns and Blunden (1980) revealed the thickest indumentum on both adaxial and abaxial epidermis of $S$. lapponum leaves in comparison to 19 species and 12 hybrids of Salix. Trichomes play a crucial role in plant defense against many herbivores. Pubescence negatively affects the ovipositional and feeding behavior, hinder the movement of arthropods on the plant surface, and reduce their access to leaf epidermis (War et al., 2012 and references therein).

During the current study, we found 8 phytophagous insect species inhabiting $S$. lapponum. The small number of herbivores can be associated with the thick indumentum of the plants. Only 3 species, namely L. caprea, A. salicina, and A. faronosa, inhabited the analyzed shoots in higher densities. However, the pest feeding caused relatively weak disruptions to host plant physiology and the S. lapponum specimens were able to maintain photosynthetic efficiency under insect attack. Comparative studies are needed to assess the species composition and population numbers of insects occurring on plants from other $S$. lapponum populations. Comprehensive knowledge of the biotic factors affecting the occurrence of downy willow would facilitate establishment of the form of S. lapponum conservation.

\section{Acknowledgments}

The study was supported by the research grant NN 304385239 from Poland's Ministry of Science and Higher Education. The plant material of S. lapponum was collected in compliance with the permits issued by the Regional Director for Environmental Protection in Lublin (Permits No. WPN.6400.1.4.2014. JR; WPN.6400.3.2015.MPR). Authors thank to two anonymous reviewers for their valuable comments, which helped improve this manuscript.

\section{References}

Beiger M (2001) Klucz do oznaczania owadów minujących roślin użytkowych, ozdobnych oraz chwastów polnych i ogrodowych: Diagnostyka szkodników roślin i ich wrogów naturalnych (ed. by J Boczek) SGGW, Warszawa, Poland, Tom 4, pp. 195-532.

Blackman RL \& Eastop VF (2017) Aphids of the world's plants: An online identification and infor- mation guide. http://www.aphidsonworldsplants. info.

Binns WW \& Blunden G (1980) Comparative leaf anatomy of Salix species and hybrids. Botanical Journal of Linnean Society 81: 205-214.

Canty R, Ruzzier E, Cronk Q \& Percy D (2016) Salix transect of Europe: patterns in the most abundant chrysomelid beetle (Coleoptera: Chrysomelidae) herbivores of willow from Greece to Arctic Norway. Biodiversity data Journal 4: e10194.

Charles JG, Nef L, Allegro G, Collins CM, Delplanque A, Gimenez R, Höglund S, Jiafu H, Larsson S, Luo Y, Parra P, Singh AP, Volney WJA \& Augustin $S$ (2014) Insect and other pests of poplars and willows: Poplars and willows. Trees for society and the environment (ed. by JG Isebrands \& J Richardson) CPI Group Ltd, Croydon, UK, pp. 459-542.

Czerniakowski ZW (2000) Willow pests on production plantations in south-eastern Poland. Progress in Plant Protection 40: 243-248.

Czerniakowski ZW (2006) Forage preferences of insects feeding on willows. Progress in Plant Protection 46: 108-113.

Czerniakowski ZW (2010) Biodiversity of noxious entomofauna on willows in south-eastern Poland. Fragmenta Agronomica 27: 19-24.

Deuschle K, Funck D, Forlani G, Stransky H, Biehl A, Leister D, van der Graaff E, Kunze R \& Frommer WB (2004) The role of 1-pyrroline-5-carboxylate dehydrogenase in proline degradation. Plant Cell 16: 3413-3425.

Fijałkowski D \& Izdebski K (2002) Poleski Park Narodowy - flora naczyniowa: Poleski Park Narodowy - Monografia Przyrodnicza (ed. by S Radwan) Wydawnictwo Morpol, Lublin, Poland, pp. 103-114.

Fürstenberg-Hägg J, Zagrobelny M \& Bak S (2013) Plant defense against insect herbivores. International Journal of Molecular Sciences 14: 1024210297.

Gatehouse JA (2002) Plant resistance towards insect herbivores: a dynamic interaction. New Phytologist 156: 145-169.

Georgiev G, Sakalian V, Ivanov K \& Boyadzhiev P (2004) Insects reared from steams and branches of goat willow (Salix caprea L.) in Bulgaria. Journal of Pest Science 77: 151-153.

Głębocka K \& Pogorzelec M (2017) Genetic diversity of the Salix lapponum L. population intended as a source of material for reintroduction. Dendrobiology 78: 136-145.

Golan K, Rubinowska K, Kmieć K, Kot I, Górska-Drabik E, Łagowska B \& Michałek W (2015) Impact of scale insect infestation on the content of photosynthetic pigments and chlorophyll fluorescence in two host plant species. Arthropod-Plant Interactions 9: 55-65. 
Hanley ME, Lamont BB, Fairbanks MM \& Rafferty CM (2007) Plant structural traits and their role in anti-herbivore defence. Perspectives in Plant Ecology, Evolution and Systematics 8: 157-178. doi:10.1016/j.ppees.2007.01.001.

Hawrylak-Nowak B, Dresler S \& Matraszek R (2015) Exogenous malic and acetic acids reduce cadmium phytotoxicity and enhance cadmium accumulation in roots of sunflower plants. Plant Physiology and Biochemistry 94: 225-234. doi:10.1016/j. plaphy.2015.06.012.

Kaźmierczakowa R \& Zarzycki K (2001) Polska czerwona księga roślin. Paprotniki i rośliny kwiatowe. Instytut Botaniki PAN, Kraków, Poland.

Kerchev PI, Fenton B, Foyer CH \& Hancock RD (2012) Plant responses to insect herbivory: interactions between photosynthesis, reactive oxygen species and hormonal signalling pathways. Plant, Cell \& Environment 35: 441-453.

Krishnan N, Kodrik D, Turanli F \& Sehnal F (2007) Stage specific distribution of oxidative radicals and antioxidant enzymes in the midgut of Leptinotarsa decemlineata. Journal of Insect Physiology 53: 67-74.

Łabanowski G \& Soika G (1998) Dangerous pests for ornamental trees and shrubs. Progress in Plant Protection 38: 172-179.

Łabanowski G \& Soika G (2003) Szkodniki ozdobnych drzew liściastych. Plantpress, Cracow, Poland.

Łukowski A, Giertych MJ, Zadworny M, Mucha J \& Karolewski P (2015) Preferential feeding and occupation of sunlit leaves favors defense response and development in the flea beetle, Altica brevicollis coryletorum - a pest of Corylus avellana. PLoS ONE 10: e0126072. doi:org/10.1371/journal. pone. 0126072 .

Maffei ME, Mithöfer A, Arimura GI, Uchtenhagen H, Bossi S, Bertea CM, Cucuzza LS, Novero M, Volpe V, Quadro S \& Boland W (2006) Effects of feeding Spodoptera littoralis on lima bean leaves. III. Membrane depolarization and involvement of hydrogen peroxide. Plant Physiology 140: 1022-1035.

Mirek Z, Zarzycki K, Wojewoda W \& Szeląg Z (2006) Czerwona lista roślin i grzybów Polski. Instytut Botaniki PAN, Kraków, Poland.

Molina-Montenegro MA, Ávila P, Hurtado R, Valdivia AI \& Gianoli E (2006) Leaf trichome density may explain herbivory patterns of Actinote sp. (Lepidoptera: Acraeidae) on Liabum mandonii (Asteraceae) in a montane humid forest (Nor Yungas, Bolivia). Acta Oecologica 30: 147-150.

Murchie EH \& Lawson T (2013) Chlorophyll fluorescence analysis: a guide to good practice and understanding some new applications. Journal of Experimental Botany 64: 3983-3998. doi:10.1093/ jxb/ert208.
Nabity PD, Zavala JA \& DeLucia EH (2009) Indirect suppression of photosynthesis on individual leaves by arthropod herbivory. Annals of Botany 103: 655-663.

Nijak K (2009) Pests as a cause of the destruction of the energy willow plantation. Progress in Plant Protection 49: 1211-1214.

Nijak K (2011) Insect species infesting different clones and cultivars of short rotation willow - a potential risk in crop protection. Progress in Plant Protection 51: 1563-1566.

Nowacka W (1996) Uproszczony klucz do oznaczania wybranych gatunków piewików (Auchenorrhyncha) występujących na uprawach roślinnych: Diagnostyka szkodników roślin i ich wrogów naturalnych (ed. by J Boczek) SGGW, Warszawa, Poland, Tom 2, pp. 103-138.

Nyman T, Paajanen R, Heiska S \& Julkunen-Titto R (2011) Preference-performance relationship in the gall midge Rabdophaga rosaria: insights from a common-garden experiment with nine willow clones. Ecological Entomology 36: 200-211. doi:10.1111/j.1365-2311.2011.01260.x.

Öquist G \& Wass R (1988) A portable, microprocessor operated instrument for measuring chlorophyll fluorescence kinetics in stress physiology. Physiologia Plantarum 73: 211-217.

Odasz-Albrigtsen AM, Tømmervik H \& Murphy P (2000) Decreased photosynthetic efficiency in plant species exposed to multiple airborne pollutants along the Russian-Norwegian border. Canadian Journal of Botany 78: 1021-1033.

Podbielkowski Z (2002) Fitogeografia części świata. Europa, Azja, Afryka. Wydawnictwo Naukowe PWN, Warszawa, Poland.

Pogorzelec M (2008) Influence of chosen environmental abiotic factors on Salix lapponum L. populations functioning in Polesie Lubelskie Region. Polish Journal of Environmental Studies 17: 139_ 144.

Pogorzelec M (2008a) The downy willow (Salix lapponum L.) population on the peat bog near Lake Bikcze (Łęczyńsko-Włodawskie Lakeland). Acta Agrobotanica 61: 91-97.

Pogorzelec M, Bronowicka-Mielniczuk U, Banach B, Szczurowska A \& Serafin A (2014) Relict boreal willows (Salix lapponum and Salix myrtilloides) as an element of phytocoenoses overgrowing the water bodies in Eastern Poland. Applied Ecology and Environmental Research 12: 441-456.

Pogorzelec M, Głębocka K, Hawrylak-Nowak B \& Parzymies M (2014a) Reproduction and diversity of the endangered Salix lapponum L. populations in Eastern Poland. Turkish Journal of Botany 38: 1239-1247.

Pogorzelec M, Banach-Albińska B, Serafin A \& Szczurowska A (2014b) Population resources of 
an endangered species Salix lapponum L. in Polesie Lubelskie Region (Eastern Poland). Acta Agrobotanica 67: 81-86.

Pogorzelec M \& Wojciechowska J (2011) The prospects for the survival of the population of a boreal relict species, Betila humilis Schrk., in a small isolated peat bog in the Łęczna-Włodawa Lakeland. Acta Agrobotanica 64: 39-46.

Rokytová L, Kula E, Kodarová L \& Pešlová A (2004) Feeding of the willow leaf beetle Lochmaea capreae L. (Coleoptera, Chrysomelidae) on leaves of birch (Betula pendula Roth) contaminated by heavy metals. Journal of Forest Sciences 50: 109-117.

Ropek D \& Frączek K (2016) Entomofauna of willow cultivated for energy purposes. Zeszyty Problemowe Postępów Nauk Rolniczych 587: 125133.

Scott-Brown AS, Gregory T, Farrell IW \& Stevenson PC (2016) Leaf trichomes and foliar chemistry mediate defence against glasshouse thrips; Heliothrips haemorrhoidalis (Bouché) in Rhododendron simsii. Functional Plant Biology 43: 1170-1182.

Santos JC \& Fernandes GW (2010) Mediation of herbivore attack and induced resistance by plant vigor and ontogeny. Acta Oecologica 36: 617-625.

Serafin A, Pogorzelec M, Banach B, Szczurowska A \& Mielniczuk J (2015) Physico-chemical groundwater conditions at Salix lapponum stands in Eastern Poland. Dendrobiology 73: 65-74.

Ścibior R (2010) The estimation of the preservation degree for wet biotopes of the Poleski National
Park based on species richness of chrysomelid (Coleoptera, Chrysomelidae) communities. Teka Komisji Ochrony i Kształtowania Środowiska Przyrodniczego - OL PAN 7: 410-419.

Urban D \& Gawlik J (2003) Stopień zróżnicowania zbiorowisk roślinnych $\mathrm{w}$ różnych typach torfowisk: Przyrodnicze podstawy ochrony i odnowy ekosystemów wodno-torfowiskowych w obszarze funkcjonalnym Poleskiego Parku Narodowego na tle antropogenicznych przekształceń środowiska przyrodniczego. Rozprawy i Monografie (ed. by S Radwan) Acta Agrophyscica 91: 166-178.

Volf M, Hrcek J, Julkunen-Titto R \& Novotny W (2015) To each its own: differential response of specialist and generalist herbivores to plant defence in willows. Journal of Animal Ecology 84: 1123-1132.

War AR, Paulraj MG, Ahmad T, Buhroo AA, Hussain B, Ignacimuthu S \& Sharma HC (2012) Mechanisms of plant defense against insect herbivores. Plant Signaling \& Behavior 7: 1306-1320.

Wrzesińska D \& Wawrzyniak M (2012) Lepidopterans (Lepidoptera) of common osier (Salix viminalis) plantations. Progress in Plant Protection 52: 248-251.

Zhu-Salzman K, Luthe DS \& Felton GW (2008) Arthropod-inducible proteins: Broad spectrum defenses against multiple herbivores. Plant Physiology 146: $852-858$. 